\title{
UPPER ELEMENTARY GRADES STUDENTS' ALGEBRAIC THINKING ABILITY IN INDONESIA
}

\author{
Vira Pratiwi ${ }^{1}$, Tatang Herman ${ }^{2}$, Dindin Abdul Muiz Lidinillah ${ }^{3}$ \\ ${ }^{1}$ S.Pd., Uiversitas Pendidikan Indonesia, Indonesia, virapratiwi@student.upi.edu, \\ ${ }^{2}$ Prof. Dr., M.Ed., Uiversitas Pendidikan Indonesia, Indonesias, tatangherman@upi.edu, \\ ${ }^{3}$ M.Pd., UPI Tasikmalaya, Indonesia, dindin_a_muiz@upi.edu \\ ${ }^{*}$ Corresponding author
}

\begin{abstract}
This research comes from an idea that algebraic thinking is one of the important things in learning mathematics for elementary school students. Algebraic thinking ability is a transitional process from arithmetic learning to algebraic learning. Students in elementary school must have aquired this ability as some prerequisite for advanced mathematics (at the level of junior high school). Aside from that, the Algebraic Thinking ability requires students to solve mathematical problems. The main purpose of this research is to describe students' algebraic thinking ability based upon algebraic-thinking characteristics, knowing the learning trajectory of learning barriers to overcome these obstacles. Therefore, the researcher conducted the research by utilizing a descriptive research method. The data were collected by means of test, interview and questionnaire on students in upper grades of elementary school located in urban areas, mid areas, also transitional regions. Based on the analysis of the results of algebraic thinking ability instrument test from 78 students, and having compared with the indicators of algebraic thinking in upper grades of elementary school in Indonesia, it shows that algebraic thinking skills of upper elementary grades in Indonesia are seemingly less good. In addition, researchers classify the barriers of algebraic thinking into three types, namely ontogenic obstacle, didactic obstacle, and epistemological obstacle, therefore with the data, the researcher generates hypothetical learning trajectory to cope with the obstacles of algebraic thinking. Learning trajectory as a result of this study will be developed as algebraic thinking design learning.
\end{abstract}

Keywords: Algebraic thinking, descriptive analysis, learning obstacles, mathematics.

\section{INTRODUCTION}

Algebraic thinking belongs to one of the most important mathematical problems in mathematical problemsolving. Algebraic thinking students' ability in Indonesia is still low (Jupri, Drijvers, Van den HeuvelPanhuizen, 2014) (you can also write Jupri et. al., et al means and friends). It is the same learning process 
that is not the student who has not been maximized so as to experience the algebra thinking. Through the algebra thinking habit prevailing and applied from elementary school, it is expected to reduce the difficulty when studying algebra formally.

Brousseau (2002, p. 10) classifies didactic obstacles into three kinds, namely ontogenic, didactic, and epistemological obstacles. Ontogenic obstacles are barriers that occur due to limited or limited neurophysiological factors. While didactic obstacles are barriers derived from a didactic situation. Learning that does not pay attention to the demands (learning trajectory) which are viewed from the stage of thinking can be a barrier in learning. As well as the epistemological obstacle, this obstacle comes from the notion of a person who is limited to certain concepts and difficulties when faced with different conditions with the same content.

The relatively low ability of algebraic thinking of the students is hampered in the representation of problems and ability in making strategies to solve mathematical problems. For example, students have difficulty in describing and analyzing numerical patterns because students do not understand the problem to be solved in a pattern and do not know how to determine the next pattern as a solution in solving math problems. This is on account of less habituation in learning to solve mathematical problems with the form of numerical and geometric patterns. Another cause, because of the weak priority of students to solve the problem-solving math problems. In addition to doing a modeling in mathematical problems, other factors are the deficiency of ability to do the problem situation modeling with objects and usage representations, such as graphs, tables, and equations to draw conclusions. Before students arrive at a formal learning about algebra, students have to have a lot of experiences in performing representation, abstract, as well as generalizing the relationship between numbers and count operations. Students should be introduced to algebraic thinking well before they are expected to be adept at manipulating algebraic symbols. In addition, students also need to learn the concepts of shapes, size, data, and opportunity in a way that connects them (Kilpatrick, 2001, p.35) (I've done the revision of this paragraph)

Blanton \& Kaput (2005, p. 7) explain that algebraic thinking can be seen as a process in which the generalizations of mathematical ideas from a set of particular instances, establish those generalizations through the discourse of argumentation, and express them in increasingly formal and age- appropiate ways. Algebraic Thinking as a transition from arithmetic to algebra has some focus that is worth noticing. First, in Algebraic Thinking students focus on the relationship of one element with other elements, not only in terms of numerical answers; but also focus on operation and inverse; Focus on causal link in solving a problem rather than solving problems without understanding meaning; Focus on numbers and letters instead of numbers; and a thorough focus on the meaning of the sign indicating equality or a relationship. These five adjustments of focus are arithmetical domains, but they also represent a shift in the idea of fundamental development for algebraic study (Cai and Knuth, 2005, p. 5). In addition, algebraic equations can offer many solutions. It gives students the opportunity to determine effective solutions and solutions that are different from the usual. This view is an important role played by teachers, in helping students to improve algebraic thinking (Barbosa \& Borralho, 2011, p. 3).

Algebraic thinking is important to be accustomed since elementary school. Kilpatrick, et al. (2001, p. 8) argues that just as the elementary and middle school mathematics curriculum should prepare students for the study of algebra, so it should also include attention to other domains of mathematics. Algebraic Thinking is a support skill for students to learn formal algebra in the next level. It should get special attention because algebra is one of the materials that is quite difficult for high school students. Several studies have shown that high school students have difficulty in learning concepts and operations of algebraic calculations (Hidayati, 2010, Marsetyorini and Murwaningtyas, 2012; Herutomo and Saputro, 2014; Permatasari, et al., 2015). In addition, the transition from arithmetic to algebran has proved to be difficult for students, and it is now widely recognized that students need an earlier opportunity to engage in algebraic reasoning in schools (NCTM, 2000 p.161). Some of the results of the research study confirm that algebraic thinking should be accustomed since primary school. Having an algebraic thinking base starting from elementary school, students are expected to reduce the difficulty in learning algebra formally.

Development of Algebraic Learning Algebra Learning in Different Countries. Research conducted in United State (Moyer, Huiker, \& Cai, 2004), Singapore (Fong, 2004), Russia (Schmittau, 2004), Korea (Lew, 2004), China (Cai, 2004), Australia (Booker \& Windsor, 2010, p.2) shows that the curriculum in primary schools has several different ways of introducing algebraic thinking. It is also clarified by Cai stating that most of the school mathematics curriculum separates arithmetic and algebra. Arithmetic became the primary focus of elementary and algebra mathematics as the main focus of high school and upper secondary mathematics. This separation makes it more difficult for students to learn algebra in the middle class $(2004$, p. 2-3). The results of Booker and Windsor (2010, pp, 7) research on seven-year-old primary school students found that 
making representations and solving problems with solutions that students acquired themselves in various ways was a step in preparing algebraic thinking. Students develop their algebraic thinking by making generalizations of the solutions they get. The Mestre \& Oliviera (2012, p. 5) Study shows that grade 4 students have begun to develop algebraic thinking. The development of algebraic thinking begins by revealing the generalization of numerical relationships in various representations. Radford's research (2010: $2011,2012)$ found that non-symbolic algebraic thinking has been shown by the student at the age of 7-8 years. Based on the results of some of these studies, it is probable that algebraic thinking can be developed in mathematics learning from elementary school.

The scope of algebraic thinking in primary schools includes generalizations based on patterns, facts, phenomena or existing data, solving problems and communicating ideas through symbols, tables, diagrams, or other media to clarify circumstances or problems (Alghtani \& Abdulhamied, 2010, p.3). Meanwhile, according to NCTM (2000, p. 158), algebra thinking of elementary school students developed into the following various indicators:

Table 1. Algebraic Thinking's Indicators

\begin{tabular}{|c|c|}
\hline $\begin{array}{l}\text { Instructional programs prekindergarten - } \\
\text { grade } 12\end{array}$ & Grades 3-5 \\
\hline \multirow[t]{2}{*}{$\begin{array}{l}\text { Understand patterns, relations, and } \\
\text { functions }\end{array}$} & $\begin{array}{l}\text { Describe, extend, and make generalizations about geometric and } \\
\text { numeric patterns }\end{array}$ \\
\hline & $\begin{array}{l}\text { Represent and analyze patterns and functions, using words, tables, and } \\
\text { graphs }\end{array}$ \\
\hline \multirow{3}{*}{$\begin{array}{l}\text { Represent and analyze mathematical } \\
\text { situations and structures using algebraic } \\
\text { symbols }\end{array}$} & $\begin{array}{l}\text { Identify such properties as commutativity, associativity, and distributivity } \\
\text { and use them to compute with whole numbers; }\end{array}$ \\
\hline & $\begin{array}{l}\text { Represent the idea of a variable as an unknown quantity using a letter or } \\
\text { a symbol }\end{array}$ \\
\hline & Express mathematical relationships using equations. \\
\hline $\begin{array}{l}\text { Use mathematical models to represent } \\
\text { and understand quantitative relationships }\end{array}$ & $\begin{array}{l}\text { Model problem situations with objects and use representations such as } \\
\text { graphs, tables, and equations to draw conclusions }\end{array}$ \\
\hline \multirow[t]{2}{*}{ Analyze change in various contexts } & $\begin{array}{l}\text { Investigate how a change in one variable relates to a change in a second } \\
\text { variable }\end{array}$ \\
\hline & $\begin{array}{l}\text { Identify and describe situations with constant or varying rates of change } \\
\text { and compare them }\end{array}$ \\
\hline
\end{tabular}

The development of algebraic thinking skills is greatly influenced by the activity of learning mathematics in the class based upon indicators presented in Table 1. Teachers play a role in determining learning activities in the classroom that can facilitate students in developing algebraic thinking skills. The learning process consisting of preparation, implementation and evaluation must be well prepared. Through design based on research it is an alternative to develop a design of students' algebraic abilities in primary school through a process of didactic situation analysis, non-taped analysis and retrospective analysis conducted cyclically.

Suryadi $(2008$, p. 6) states that teaching materials should be designed in such a way that students find concepts, procedures, or principles not directly but through a series of activities. Therefore, teachers should be able to present didactic activities that facilitate students to develop algebraic thinking and overcome student learning barriers. The learning barriers that students experience in learning can be predicted when teachers design the lessons to be presented. By analyzing the learning obstacles facing students, teachers can present didactic designs in the form of Hypothetical Learning Trajectory (HLT) that can help students develop algebraic thinking according to the instructional sequences presented by the teachers. The purpose of this research is to describe algebraic thinking ability of upper elementary grades students based on algebraic thinking characteristic, to know the factors causing algebraic thinking barrier and make learning trajectory to overcome the obstacles. 


\section{RESEARCH METHODOLOGY}

This research will describe algebra thinking process of learning of upper elementary grades students and algebra thinking characteristics of upper elementary grades students. Research is carried out by determining problems and preliminary studies in the form of literature studies and discussions with various parties to obtain preliminary information on the issues to be studied. The next step has been to formulate the research problem in the form of questions whose answers should be sought through research and formulate the research problem, then have chosen the approaches, the research method in accordance with the formulation of research problems, has determined the data source, and has chosen data collection techniques, and data analysis techniques. The data collection was done after the instrument is completed. The data that have been obtained are analyzed and drawn upon the conclusion.

The participants of the study were selected by making use of a purposive random sampling technique. The researcher has selected sample data sources by considering the focus of the research, so that the sample data sources in this study are teachers and students of elementary school. The data collection technique that has been used in this study is triangulation in the form of tests, interviews and questionnaires. In this study the researcher is the main instrument. The researcher stands as the main instrument role to set the focus of research, determine the source data, collect them, analyze them, and conclude them based based on her understanding. But the researcher also uses auxiliary instruments to collect data.

The students' algebraic thinking tests and interviews were conducted on algebra learning of sixth elementary grade students. The tests were upon 78 students from three different elementary schools. Each school consists of 26 students. The test instrument has been validated by the expert and elementary school teacher, beside that, the researcher distributes the questionnaire after the process of questioning to the students. The results from the questionnaire stated that some students said they could answer the given questions. Students understood the problems and they found the problems in their daily lives. Students also said that they never get any problems related to algebraic thinking from their teachers in class IV-VI. Most students felt that the time provided was enough to do the problem and believed that the answers given were correct. However, there were some students who faced difficulty in determining the purpose of the given problem, that the student must read many times, asked the teacher about the purpose of the questions. This is because the ability of problem representation in some students was still low. On the other hand, the given problems have been validated by the team of experts and teachers, with the validation that the problem of algebraic thinking given was good and varied.

The data analysis technique used in this research refers to the technique proposed by Miles and Huberman, (2013, pp. 1) which consists of: (1) data reduction; (2) data presentation (data display); (3) conclusion drawing.

\section{FINDINGS AND DISCUSSION}

\subsection{Findings}

\subsubsection{Learning Process}

Learning algebraic thinking in upper elementary grades is not included in the curriculum, but it is implied in some basic competencies that use algebraic thinking processes. The relation between clgebraic thinking indicators and mathematics curricula are:

Table 2. Basic Competence of Algebraic Thinking

\begin{tabular}{|l|c|}
\hline \multicolumn{1}{|c|}{ Characteristics of Thinking } & Basic Competition \\
\hline $\begin{array}{l}\text { Describing, extending, and making } \\
\text { generalizations about geometric and } \\
\text { numeric patterns; }\end{array}$ & $\begin{array}{c}\text { 4.11 Predicting the pattern of plane and space sequence by } \\
\text { using concrete models }\end{array}$ \\
\hline $\begin{array}{l}\text { Representing and analyzing patterns } \\
\text { and functions, using words, tables, } \\
\text { and graphs. }\end{array}$ & $\begin{array}{l}4.8 \text { Identifying space ithat constructed from another spaces, } \\
\text { also determining its surface area and volume }\end{array}$ \\
\hline $\begin{array}{l}\text { Expressing mathematical relationships } \\
\text { using equations. }\end{array}$ & $\begin{array}{l}\text { 4.3 Solving the problem about predicting the result of addition, } \\
\text { substitution, multiplication and devision of counting } \\
\text { number and fractions }\end{array}$ \\
\hline
\end{tabular}




\begin{tabular}{|c|c|}
\hline \multirow{3}{*}{$\begin{array}{l}\text { Modeling problem situations with } \\
\text { objects and using representations } \\
\text { such as graphs, tables, and equations } \\
\text { to draw conclusions }\end{array}$} & $\begin{array}{l}\text { 3.3 Explaining and making doing predicting the result of } \\
\text { addition, substitution, multiplication and devision of } \\
\text { counting number and fractions }\end{array}$ \\
\hline & $\begin{array}{l}\text { 4.3 Solving problems which related to multiplication and } \\
\text { division of fractions }\end{array}$ \\
\hline & $\begin{array}{l}\text { 4.10 Organizing and presenting data which related to students } \\
\text { it self and comparing it with data from the surrounding } \\
\text { environment in form of table, picture diagram (pictogram), } \\
\text { bar charts, or line charts }\end{array}$ \\
\hline
\end{tabular}

Based on the results of interviews conducted on upper elementary grades teachers, it can be seen that the ability of students about the pattern of mathematics in the form of numbers and plane is still deficient. Some obstacles found in learning about patterns are the deficiency of basic ability in logic that makes students face difficulty in reasoning. In addition, students experience technical problems in doing the problem such as accuracy, and carelessness in the process of making the problem. Thus, the deficiency of students' skills on the patterns impacts the ability to analyze patterns and present them in other forms in Table 2. On the other hand, most students have mastered the skill in using the "=" symbol to apply relationships between varying numbers and predictive set. However, during the learning process it is still found obstacles in understanding the problem. Students should be assisted in representing the problem so that it is understood that the solution of the problem with the use of the symbol "=". The students' ability regarding representation, such as graphs, tables, modeling etc., is still very Iminimal. This is due to the deficiency of habituation in using graphs and tables in learning. In addition, there are some suggestions in learning algebraiac thinking, which should be accustomed since lower elementary grades, so that when they are in upper elementary grades they will have already been accustomed to algebraic thinking activities. Furthermore, as they go into junior high school, they have already had good skills in formal algebra.

\subsubsection{Results of the Algebraic Thinking Test of Upper Elementary Grade Students}

The research findings indicate that there are students who are able and unable to work on the algebraic thinking test instrument. After doing the data field analysis, the data of upper elementary grades students' algebraic thinking are as follows:

Table 3. Results of the Algebraic Thinking Test

\begin{tabular}{|l|c|c|c|}
\hline \multicolumn{1}{|c|}{ Problem Indicators } & No. Test & $\begin{array}{c}\text { Correct } \\
\text { answer }\end{array}$ & $\begin{array}{c}\text { Percentage } \\
\text { (\%) }\end{array}$ \\
\hline Finding a plane pattern & 1 & 41 & $53 \%$ \\
\hline Create a table based on pattern & 2 & 39 & $50 \%$ \\
\hline $\begin{array}{l}\text { Resolving open-ended problems about the appraisal of } \\
\text { the sum, difference, counting number }\end{array}$ & 3 & 59 & $76 \%$ \\
\hline $\begin{array}{l}\text { Completing the breakdown of the chest count } \\
\text { assessment }\end{array}$ & 4 & 40 & $51 \%$ \\
\hline $\begin{array}{l}\text { Solving problem } \\
\text { multiplication ofmultiplication and division of fractions }\end{array}$ & 5 & 44 & $56 \%$ \\
\hline Creating charts and organize table data. & 6 & 37 & $47 \%$ \\
\hline \multicolumn{2}{|c|}{ Average } & & $55.5 \%$ \\
\hline
\end{tabular}

From the Tabel 3. above, it can be seen that $53 \%$ of students can describe, convey, and generalize about geometric and numerical patterns. Problems that can be done by students in finding patterns and counting 
the number of triangles measure the ability in describing, conveying and making a generalization of geometric patterns. Through the question the students are required to perform an activity of thinking, and to search out using their own strategy, both in real and imaginative ways about a pattern that is right to find the answer on the matter. After the students find the right pattern then the student will look for small triangle number as the smallest elements in the pattern according to the order in question. At the time of the process of looking for the right pattern occurs in the examples in the minds of students called algebra thinking.

Meanwhile, the number of students who are able to show and analyze patterns and functions, using words, tables, and graphs is about $50 \%$. Students' algebra thinking process is shown by the activity of finding a pattern of cube tower by counting its surface, then the students record the result of pattern analysis into the table. Recording process of the data found into the table is an algebraic thinking activity that occurs in students. The number of students who can express mathematical relationships using the same marks occupies the highest percentage of $76 \%$. In the process of solving the open question of a counting operation, the student will try to look for possible answers. The possibilities that the test student takes into consideration the meaning of the symbols contained in the counting operation. Thus students experience algebraic thinking processes in search of possible answers to find the right answers.

In algebraic thinking indicators model the problem situation with objects and usage representations, such as graphs, tables, and equations to draw conclusions, about $51 \%$ of students are able to do so. Problems which developed in this inductor include the problem-solving problem of chopping, problem-solving of multiplication and or multiplication of fractions, charting and organizing table data. The process of working on the problemsolving problem, the students interpret the existing in the problem into the form of numbers. Through this process the students are able to know the equations logically and determine the answers to the questions given. Meanwhile, when solving the problem of multiplication and or multiplication of fractions, students solve it by using a proper modeling with the situation in question. After doing a modeling the student will know a value in the same unit then find the right answer. Meanwhile in the problem of making graphs and organizing table data, students present the same data in different forms. The process in the presentation is algebraic thinking skills.

Therefore, it can be known that the average algebra thinking ability of the students is $55 \%$. The average grades obtained by all students are classified into five categories. According Purwanto (2006, p. 82) the Classififcation is:

Table 4.Category of Values

\begin{tabular}{|c|c|}
\hline Value & Category \\
\hline $90-100 \%$ & Very good \\
\hline $80-89 \%$ & Good \\
\hline $65-79 \%$ & Enough \\
\hline $55-64 \%$ & Less good \\
\hline$<55 \%$ & Less \\
\hline
\end{tabular}

It can be concluded that based on algebraic thinking indicators, the algebraic thinking ability of upper elemntar grades is less good.

\subsection{Discussion}

\subsubsection{The Upper Elementary Grade Students' Algebraic Thinking Ability}

Generally, the development of elementary school mathematics curriculum is directed to improve students' life skills. Mathematics learning is aimed at students having the competence of spiritual attitudes, social attitudes, knowledge, and skills. Algebraic thinking is one of the mathematical skills that must be mastered by elementary school students. Algebraic skills are explicitly contained in some basic competencies in the upper elementary class. The learning includes about the concept of pattern analyzing patterns and presenting in other forms (tables), using symbols " $="$, and graphical representations, tables, modeling etc.

In general, the pre-algebra learning process in the baseline consists of opening, content and cover. The implementation of pre-algebra learning is adapted to the right method, but there are still some obstacles. These constraints come from students and teachers. Students are constrained by the knowledge of natural 
preconditions of algebraic thought that is deficiency; it is due to deficiency of habituation in using graphs and tables in learning. While teachers are constrained from the delivery of coherent material. This is because students are not accustomed to think algebra since low grade elementary school, so there are steps that are missed to build algebraic thinking competence.

\subsubsection{Algebraic Thinking' Obstacles}

Learning obstacles can be used by teacher for designing algebraic thinking learning. Kinds of learning obstacles are ontogeny obstacle, didactical obstacles obstacle that caused by student's inability or limitedness neurophysiologist. These genetic factors seem to make students difficult to explain the meaning of something. So they will have difficulty in connecting and learning a new condition in their daily lives.

Didactical obstacle comes from some didactical situation. This obstacle is dependent on its educational system. So, it is very connected to the term so-called "hypothetical learning trajectory". While learning trajectory is forbidden, it will become a big problem for students to understand learning. Beside that, the complexity of subject matter also effects the success of learning activity. It should be arranged from the simplest part to the complex one.

Epistemological obstacle (Brouseau, 2002, p.83) fundamentally is people's knowledge for certain context. If the people are faced to another context, they will get confused, difficult or unable to use their knowledge

While some wrong answers can be seen in the figures below:

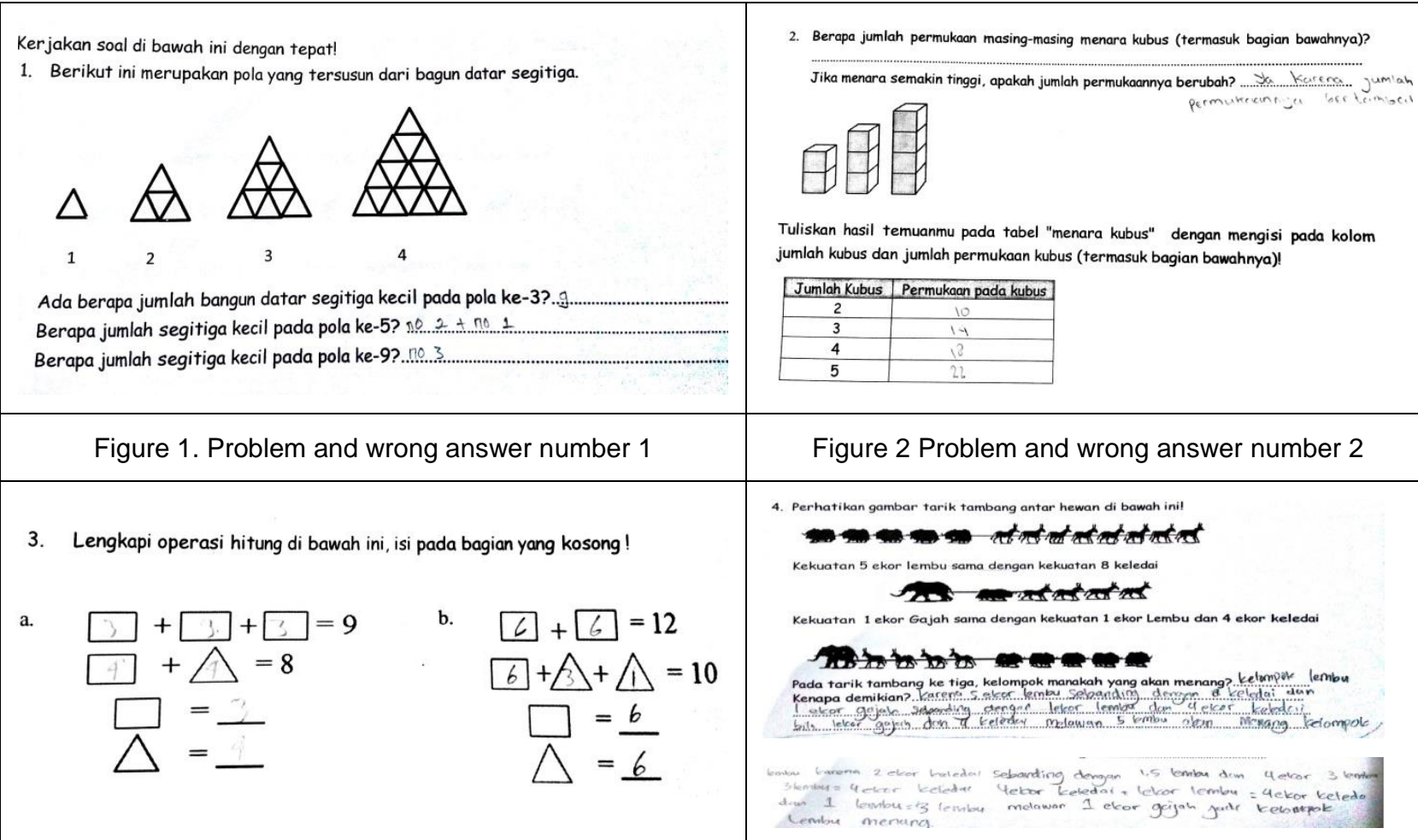

\begin{tabular}{|r|l|}
\hline Figure 3. Problem and wrong answer number 3 \\
\hline 5. Beratnya Ikan Bawal & $\begin{array}{l}\text { Keterangan: } \\
\text { Berat kepala Ikan } \frac{1}{3} \text { dari seluruh bagian ikan } \\
\text { Berat ekornya } \frac{1}{4} \text { dari seluruh bagian ikan } \\
\text { Berat badannya } 300 \text { gram }\end{array}$ \\
\hline
\end{tabular}

Lalu, berapakah berat keseluruhan bagian ikan itu?

$\frac{1}{3}+\frac{1}{9}=\frac{4+3}{12}-\frac{7}{12}-\frac{12}{12}-\frac{7}{12}=\frac{1}{12}$

Figure 5 .Problem and wrong answer number 5
Figure 4. Problem and wrong answer number 4

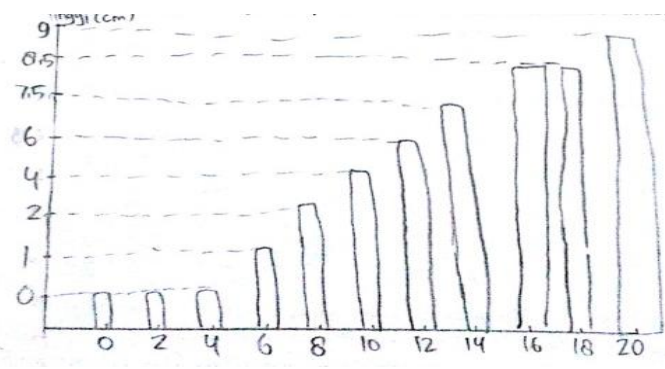

Figure 6. wrong answer number 6 
The answer of Figure 1 shows that student know number of triangles in one pattern but do not understand for next pattern. In Figure 2, student's answer is not accurate in determining the number of cube surfaces. As for Figure 3, student can determine number operation correctly, but it is uncorrect for context of the problem as shown. Problem here shows meaningful rectangle and triangle plane. In Figure 4, student confuses to determine the value of each plane so the answer is uncorrect. Furthermore, in Figure 5 students can not determine the weight of each piece of fish, so difficult to find the total weight of fish. In Figure 6 student do mistake in making graphs in accordance with the data given. To explain days $0-4$ in $x$-axis, student false in determining position of point 0 and has difficuly in determining its coordinates.

Beside using test instrument, researchers conducted interviews on nine students with attention to high, middle and lower student abilities. Following some interview conversations.

$Q$ : How did you answer the question number 1 ?

S2: By summing the mount of triangles, then adding and multiplying by 4

$\mathrm{Q}$ : How did you answer the question number 2?

S2 : By calculating number of cubes then adding it

$\mathrm{Q}$ : How did you answer the question number 3 ?

S2 : By looking for a number that when it adding each other will produce 9 , also for 8 , and I find $4+4$

$\mathrm{Q}$ : How did you solve the problem number 4 ?

S2 : Elephant and donkey group, because I assume that elephants are heavier and stronger.

$\mathrm{Q}$ : How did you solve the problem number 5 ?

S2 : By calculate it that $1 / 3 \times 300,1 / 4 \times 300$ Then summing all of its parts.

$\mathrm{Q}:$ How did you answer the question number 6 ?

S2: Make the graph is easy

Meanwhile, the example of interview transcript 2 shows the students who, as a whole, has not been able to do algrebraic thinking well It can be seen from the question no 1, the students is able to show a small triangle in a pattern, but he has not known the strategy used to find out the following pattern. The same thing happens in question 2, the students know that there is a change in the number of surfaces on the cube tower, but he can not determine the number of surfaces in the existing cube towers, and the cube tower 5 . In question no 3 , the student knows that he must find the right number in the counting operation on the question, but he does not ignore the symbols of rectangles and triangles that have their own meaning. Besides, the student also can not explain the rationale reason in answer no 4, the student replied that he saw from the nature that elephant has a great strength so that elephant group and four donkey are able to win the tug of war. Similarly to questions no 5 and 6 , in question no 5 the student cannot correctly interpret the question and he assume that the overall weight of the fish is $300 \mathrm{grams}$, so they look for the head and tail of the fish by multiplying the fractions by $300 \mathrm{gram}$. While on the question no 6 of 6 can not explain the meaning of the graph he made, other than that there was a mistake in placing the zero in the cartesius line.

Based on the above description, the obstacles of algebraic thinking that occur in upper elementary grades are obstacles in describing, conveying, and generalizing about geometric and numerical patterns, and barriers in showing and analyzing patterns and functions, using words, tables, and graphs, obstacles in showing mathematical relationships by using equal signals, as well as obstacles in modeling problem situations with objects and using representations, such as graphs, tables, and equations to draw conclusions.

\subsubsection{Learning Trajectory}

Kansanen (in Suryadi, 2008, p.s 7) argued that the relation between teacher - content - student is represented in the figure of didactical triangle. The relation between teacher and student is called Pedagogical Relation (PR) while the relation between student ant content is called as Didactical Relation (DR) and the relation between student and content can be anticipated by making its learning trajectory. Learning trajectory has functioned to know the arrange of subject matter that should be explained so it can lead student' development systematically. Learning trajectory include prerequisite knowledge for the matter that will be learned. Anticipated by making its learning trajectory. Learning trajectory has function to know the arrange of subject matter that should be explained so it can lead student' development systematically. Learning trajectory include prerequisite knowledge for the matter that will be learned. 
No now we will talk about of four main prerequisite knowledge that will be used in this explanation. They are the prerequisite of learning to make pattern, to describe pattern, to communicate mathematical relation by using equality sign and the last one is to model a problem. The prerequisite knowledge in learning to make pattern in mathematics is computational concept, such as addition, substitution, multiplication, division. It will be begun from learning about simple pattern in the plane (geometrical pattern), continue to more complex geometrical pattern and then learn about simple until complex numerical pattern. The prerequisite knowledge in describing patterns, tables and graphs is introduction of statistics, concept of patterns, tables and graphs, datum/data in single or group form. Teacher holds main role to make student accustomed to understand about data, may be it can be did by asking students to read and analyze data given. The prerequisite knowledge in communicating mathematical relation by using equality sign is fundamental concept of symbols in mathematics, such as adding, substituting, dividing sign, numeric operation, and understanding of the meaning of numbers that located in left or right side of its equality sign. After that students will be thought to complete a numeric operation by its open ended question. The prerequisite knowledge in modeling a problem in mathematics (most of content in mathematics are able to represent by using model), students must have creativity to making another representation, such as using variable to change word problem into mathematical sentences. Then, students choose right strategy to solve the problem by using its model.

Now we will talk about of four main prerequisite knowledge that will be used in this explanation. They are the prerequisite of learning to make pattern, to describe pattern, to communicate mathematical relation by using equality sign and the last one is to model a problem. The prerequisite knowledge in learning to make pattern in mathematics is computational concept, such as addition, substitution, multiplication, division. It will be begun from learning about simple pattern in the plane (geometrical pattern), continue to more complex geometrical pattern and then learn about simple until complex numerical pattern. The prerequisite knowledge in describing patterns, tables and graphs is introduction of statistics, concept of patterns, tables and graphs, datum/data in single or group form. Teacher holds main role to make student accustomed to understand about data, may be it can be did by asking students to read and analyze data given. The prerequisite knowledge in communicating mathematical relation by using equality sign is fundamental concept of symbols in mathematics, such as adding, substituting, dividing sign, numeric operation, and understanding of the meaning of numbers that located in left or right side of its equality sign. After that students will be thought to complete a numeric operation by its open ended question. The prerequisite knowledge in modeling a problem in mathematics (most of content in mathematics are able to represent by using model), students must have creativity to making another representation, such as using variable to change word problem into mathematical sentences. Then, students choose right strategy to solve the problem by using its model.

For the next research, learning trajectory as a result of this study will be developed as a design learning. The purpose of this design learning is to developing didactical learning to solve algebraic thinking problems, especially for upper grade of elementary school' students.

\section{CONCLUSION}

Algebraic thinking learning in upper elemetary grades is not included in the curriculum, but it is implied in some basic mathematical competencies that use algebraic thinking processes. the study of algebraic thinking skills in elementary schools, especially upper elementary grades, is needed to make the design of learning tailored to the elementary school mathematics curriculum. the study reveals that the average student's ability to think algebra in algebraic thinking is 55.5\%. It means that based on the indicators of algebraic thinking, the algebraic thinking ability of upper elementary grades is less good. Also found obstacles to algebraic thinking that occur in students are obstacles in describing, conveying, and making generalizations about geometric and numerical patterns, and obstacles in showing and analyzing patterns and functions, using words, tables, and graphs, barriers in showing a mathematical relationship by using equal signals, as well as obstacles in modeling the problem situation with objects and using representations, such as graphs, tables, and equations to draw conclusions. Based on the obstacles of thinking thought that have been found, such have been generated Hypothetical learning

Trajectory to develop algebraic thinking learning design.

\section{ACKNOWLEDGEMENT}

The research was financially supported by Indonesia Endowment Fund for Education (LPDP). LPDP which is managed by the Ministry of Education and Culture, the Ministry of Finance, the Ministry of Religious Affairs and the Ministry of Research and. The opinions expressed in this article are those of the author and do not necessarily represent the views of the institute or the scholarship sponsor. 


\section{REFERENCE LIST}

Alghtani, O. A., \& Abdulhamied, N. A. (2010). The effectiveness of geometric representative approach in developing algebraic thinking of fourth grade students. Procedia - Social and Behavioral Sciences, 8(5), 256-263. https://doi.org/10.1016/j.sbspro.2010.12.035 Barbosa, E., \& Borralho, A. (2011). Exploring patterns in algebraic thinking, 7, 2914-2915.

Barbosa, E., \& Borralho, A. (2011). Exploring patterns in algebraic thinking, 7, 2914-2915

Blanton, M., \& Kaput, J. (2005) Characterizing a Classrooom Practice that Promote Algebraic Thinking. Journal for Research in Mathematics Education, 36 (5), 412-446.

Booker, G., \& Windsor, W. (2010). Developing algebraic thinking: Using problem-solving to build from number and geometry in the primary school to the ideas that underpin algebra in high school and beyond.Procedia - Social and Behavioral Sciences, 8(5), 411-419. https://doi.org/10.1016/j.sbspro.2010.12.057

Brousseau, G. (2002). Epistemological Obstacles, Problems, and Didactical Engineering . Theory of Didactical Situations in Mathematics: Didactique Des MathEmatiques, 1970-1990 , (1 983), 79-117.

Cai, J. (2004). Developing Algebraic Thinking in the Earlier Grades : A Case Study of the Chinese Elementary School Curriculum 1. The Mathematics Educator, 8(1), 107-130.

Cai, J., \& J.Knuth, E. (2005). Introduction : The Development of Students' Algebraic Thinking In Earlier Grades From Curricular, Instructional and Learning Perspectives. Zdm, 37(1), 1-4.

Fong, N. S. (2004). Developing Algebraic Thinking in Early Grades: Case Study of The Singapore Primary Mathematics Curriculum. The Mathematics Educator. Vol. 8 No. 1. 39-59.

Herutomo, R. A. dan Saputro, T. E. M. (2014). Analisis Kesalahan dan Miskonsepsi Siswa Kelas VII Pada Materi Aljabar. Edusentris, Jurnal IImu Pendidikan dan Pengajaran, Vol. 1 No. 2, hal. 134-145.

Hidayati, F. (2010). Kajian Kesulitan Belajar Siswa Kelas VII SMP Negeri 16 Yogyakarta dalam Mempelajari Aljabar. Skripsi Universitas negeri Yogyakarta. Dipublikasikan

Jupri, A., Drijvers, P., \& Van den Heuvel-Panhuizen, M. (2014)....Difficulties in initial algebra learning in Indonesia. Mathematics Education Research Journal 26 (4), 683-710

Kilpatrick, J., Swafford, J., \& Fidell, B. (2001). Adding It Up: Helping Children Learn Mathematics. Washington, DC: national Academy Press.

Lew, H. C. (2004). Developing Algebraic Thinking in Early Grades: Case Study of Korean Elementary School Mathematics. The Mathematics Educator. Vol. 8 No. 1. 88-106.

Marsetyorini, A. D. dan Murwaningtyas, C. E. (2012). Diagnosis Kesulitan Belajar Siswa dan Pembelajaran Remedial dalam Materi Operasi Pada Pecahan Bentuk Aljabar Di Kelas VIII SMPN 2 Jetis Bantul. Prosiding Makalah dipresentasikan dalam Seminar nasional Matematika dan Pendidikan Matematika "Kontribusi Pendidikan Matematika dan Matematika dalam Membangun Karakter Guru dan Siswa". Jurusan Pendidikan Matematika FPMIPA UNY

Mestre, C. \& Oliveira, H. (2012). From Quasi-Variable Thinking to Algebraic Thinking: A Study With Grade 4 Students. [Online]. Diakses dari http://repositorio.ul.pt/bitstream/10451/7087/1/Mestre Oliveira ICME12.pdf

Miles, M. B. \& Huberman, A. M. (1984). Qualitative Data Analysis: A Sourcebook of New Methods. California; SAGE publications Inc.

Moyer, J., Huinker, D. A., \& Cai, F. (2004). Developing Algebraic Thinking in the Earlier Grades: A Case Study of the U.S. Investigations Curriculum. The Mathematics Educator. Vol. 8 No. 1. 6-38.

NCTM. (2000). Principles and Standards for School Mathematics. Reston, V.A: NCTM.

NCTM. (2014). Principles to Actions: Ensuring Mathematical Success for All. Reston, V.A: NCTM.

Permatasari, B. A. D., dkk. (2015). Analisis Kesulitan Siswa dalam Menyelesaikan Soal Materi Aljabar Siswa Kelas VIII SMP Negeri 2 Bangil. Kadikma, Vol. 6, No. 2, hal 119-130.

Purwanto, M. N. (2006). Prinsip-prinsip dan teknik evaluasi pengajaran. Bandung: PT Remaja Rosdakarya.

Radford, L. (2010). Elementary Forms of Algebraic Thinking in Young Students.In M. F. Pinto.\& T. F. 
Kawasaki (Eds.).Proceedings of the 34th Conference of the International Group for the Psychology of Mathematics Education, Vol. 4, p. 73-80. Belo Horizonte, Brazil: PME.

Radford, L. (2011). Embodiment, perception and symbols in the development of early algebraic thinking.In Ubuz, B. (Ed.), Proceedings of the 35th Conference of the International Group for the Psychology of Mathematics Education (Vol. 4, p. 17-24). Ankara, Turkey: PME.

Radford, L. (2012). On the development of algebraic thinking.PNA 64(1), 117-133.

Schmittau, J. \& Morris, A. (2004). The Developing of Algebra in Elementary Mathematics Curriculum of V.V. Davydov. The Mathematics Educator. Vol. 8 No. 1. 60-87.

Suryadi, D. (2010). Didactical Design Research (DDR) dalam Pengembangan Pembelajaran Matematika1. Seminar Nasional Pembelajaran MIPA Di UM Malang, 13 November 2010 SEMNAS MIPA 2010 UTAMA, (November), 1-75. 